Serohina Nataliia

Phd of Economic Sciences, Associate Professor

Department of Economics and Entrepreneurship

Odessa State Academy of Civil Engineering and Architecture

(Odessa, Ukraine)

Petryshchenko Nataliia

Phd of Economic Sciences, Associate Professor

Department of Economics and Entrepreneurship

Odessa State Academy of Civil Engineering and Architecture

(Odessa, Ukraine)

Andrlic Berislav

Doctor of Economy, Professor

Polytechnic in Pozega

(Pozega, Croati)

\title{
DIGITAL MARKETING IN HOTELS
}

The article analyzes scientific sources, which found digital marketing the most relevant for businesses in any industry nowadays and is used by different types of markets. It was identified that it benefits due to a variety of tools and an interactive format that allows the end user to receive up-to-date resource information, comment, and stakeholder engagement, which has a positive impact on the stakeholder circle. The basic tools of digital marketing are presented, the scheme of graduation of digital marketing using by type and breadth of possibilities is developed. It has been found that digital marketing activities and tools cannot be effectively used in hotel business without further service, especially in the hotel business.

Keywords: digital marketing; Internet marketing; digital marketing tools; hotel business; digital technology.

\section{DOI: $10.15276 / \mathrm{mdt} .3 .3 .2019 .4$}

Statement of the problem in general form and it's connection with important scientific or practical tasks. Marketing is the basis for the development of any enterprise. Every year, marketing technologies are changing along with production technologies and current global trends. The globalization of the world economy and the informatization of communications and logistics are catalysts for the rapid aging of technologies and products. In such circumstances, the functioning of enterprises and business entities can not be slow, these factors are pushing for intensive development, restructuring, active use of the latest technologies. The development of marketing is rapid, the main areas are customer personalization, use of Internet marketing channels, the focus of advertising on selected groups of users, digital technologies in marketing. Digital awareness is an important feature for the modern man, but in the hotel business of Ukraine, the use of digital marketing technologies is quite low.

(C) 2019 The Authors. This is an open access article under the CC BY license (http://creativecommons.org/licenses/by/4.0) 
Analysis of the latest research and publications, which initiated the solution of this problem and on which the author relies. The development of digital technologies in Ukraine was investigated in the works of Oklander M.A., Romanenko O.O. [1], Yatsyuka D.V. [2], Lyulchak Z.S., Matviyev M.Y. [3], Danko T.P., Skorobogatyh I.I., Gerasimyak N.V., Datsenko V.V. and other scientists. The role of digital marketing in the activity of modern enterprise is considered in the works of Ruban V.V. [4], Marchuk O.O. [5], Savitskaya N.L. Features of use of digital marketing and technologies at the enterprises of the hotel business were covered in the works of Zubareva M.A. [6], Oklander T.O., Ossetian O.M., Khidirova S. [7], Khimich I.G., Humeniuk N.V., Palamarchuk A.O., Kononenko T.P., Timofeeva O.M., Usinoy A.I. and many others.

Selection of previously unresolved parts of the general problem addressed by the article. The diversity of researchers' views and the vast number of scientific and practical advances in digital marketing theory and practice underline not only the relevance of this topic in today's economy, but also the many tools, methods and activities inherent in this particular area of marketing. A separate debate is the identification of digital and internet marketing. Aspects of the functioning of digital marketing and digital technologies in the hotel sphere are not sufficiently considered, which, in turn, intensifies the need of an in-depth study of the features of its use.

Formulation of the purpose of the article (statement of the problem). The purpose of the article is to identify the main characteristics, methods and tools of digital marketing, as well as to identify the main areas of use of digital marketing and technology in the hotel business.

Statement of the main material of the research with full justification of the scientific results obtained. The term "digital marketing" is quite broad and implies the use of all possible forms of digital channels to promote a product or service. To clarify the meaning of the term and to classify digital marketing forms and tools, scientists have worked out the theories and found the concepts listed in Table 1.

Table 1 - Interpreting Digital Marketing

\begin{tabular}{|l|l|}
\hline \multicolumn{1}{|c|}{ The authors } & \multicolumn{1}{|c|}{ Definition } \\
\hline $\begin{array}{l}\text { Oklander M.A., } \\
\text { Romanenko O.O. [1] }\end{array}$ & $\begin{array}{l}\text { A type of marketing activity that, through digital channels, by digital } \\
\text { methods, enables targeted targeting to engage with target market } \\
\text { segments in virtual and real environments. }\end{array}$ \\
\hline $\begin{array}{l}\text { Danko T.P., } \\
\text { Skorobogadyh I.I. [8] }\end{array}$ & $\begin{array}{l}\text { Digital marketing is a marketing that engages with customers and } \\
\text { business partners using digital information and communications } \\
\text { technologies and electronic devices, in a broader sense it is marketing } \\
\text { activities using digital information and communication technologies. }\end{array}$ \\
\hline $\begin{array}{l}\text { Marchuk O.O. [5] } \\
\text { Zubareva M.A. [6] }\end{array}$ & $\begin{array}{l}\text { Digital marketing is a general term for the marketing of goods and } \\
\text { services that uses digital channels to attract and retain customers and } \\
\text { includes internet marketing. }\end{array}$ \\
\hline
\end{tabular}

Thus, it should be noted that digital marketing is an advanced concept of Internet marketing and allows not only to use online technologies, but also to interact with offline customers, personalize their needs.

They use this type of marketing in both individual and industrial markets. The variety of tools and the interactive form allow the end user not only to get up-to-date information about the necessary resource, but also to leave feedback, to widen the circle of interested persons. Getting information is almost instantaneous, which has a positive impact on the consumer and 
stakeholder community. According to ZS It is in this context that the popularity of the use of progressive interactive tools in marketing activities, which can carry out both effective positioning of the company, brand and generate customer loyalty on the basis of digital technologies, is increasing [9]. The most promising in the use of digital marketing in the hotel business are social networks that offer vacations and temporary accommodation for different price categories. These factors have, over the past years, led to the active development of Social Media Marketing (SMM), ie marketing that is responsible for working with social resources, creating content, securing user engagement, reviews that are targeted by other potential consumers and other diverse marketing tools.

The main tools of digital marketing are the following:

- Mobile marketing - one of the most relevant areas of modern marketing, which provides the possibility of a two-way channel of communication with the end consumer, accessibility, personalization;

- E-mail marketing - on this basis the majority of sales funnels in Ukraine is built, but the functions of spam filtering and setting up modern mail services do not allow to use this type of marketing quite effectively;

- Online commerce is a very advanced way of selling goods and services, attracting attention to production, but there are some groups of consumers who want to receive information at a convenient time, and buy only after direct contact. To the same direction include the active development of marketplaces - trading venues - online; use of social networks; Ad sites;

- Influencer Marketing - presenting information to celebrities who have influence or authority in a specific target audience. Advantages of this method can be considered wider coverage of the target audience, additional attention to the brand, gaining some trust in the product;

- Chatbots - a kind of virtual assistants that increase convenience for consumers, automatically generate message sending, can be used around the clock both in communication functions with consumers and in attracting new target audiences;

- SEO (Search Engine Optimization) - search engine optimization, that is, bringing the information resource (site, etc.) to the ideal state in the technical and informational parts, which, in turn, allows to increase the parameters of information output when the search engines work;

- PPC (Pay Per Click) - An online contextual ad associated with a specific search query (keyword). Allows you to increase your target audience and increase consumer awareness of products and services.

- Event Marketing is a separate synthetic marketing communications tool, which is a multi-component complex that includes a huge list of marketing and advertising activities. Event marketing stimulates the interest of the target group through special events aimed at attracting a large number of participants not only as prospective consumers, but also as partners, representatives of information channels.

The digital marketing application has several levels in terms of usage type and breadth of opportunities (Fig. 1).

The development of digital marketing, both in general and in the field of hotel business, depends directly on such factors as: customer loyalty in pricing; convenience (interaction time 24/7); mobility (modern devices allow you to receive information and pay for a product or service anywhere); brand trust (a pre-requisite for regular use items purchased through online ordering). Modern changes in the globalized environment are creating new demands on marketing in general and its components, including marketing research, marketing in the Internet environment and marketing communications. Thus, digital marketing is nowadays widely used as a tool for influencing consumers [10]. 
Entry Level: Online Presence, Mailbox, Social Media Page

Enhanced level: advanced features of Internet technology

capabilities (online ordering, interaction between

manufacturer of goods and services and end consumer)

High level of marketing automation: use of modern digital technologies, which for the most part provide marketing activities on the Internet

Figure 1. Levels of use of digital marketing

Consideration should also be given to addressing the main trends in information technology that support the promotion of digital marketing. Yes, it is impossible to effectively use digital marketing activities and tools in modern life without further service, especially in the hotel business. An example would be the situation where the hotel has a page, has an email address, has modern accounting systems and advertising activities on the Internet, but it is not possible to make online orders at a convenient time. That is, every step in the development of digital marketing must be supported by the development of related advanced technology technologies.

The hospitality industry is currently one of the most promising in terms of efficiency gains through the use of a variety of information technology systems, relying on a large number of digital marketing tools. The fact that tourism is one of the top five (and according to some according to some three) industries with the highest share of sales of goods and services via the Internet speaks about the increase in the use of information technologies [11].

Thus, according to the State Statistics Committee of Ukraine [12], in 2018 there is an increase in the number of collective placement facilities, which confirms the calculation of the growth rate: in 2017-2018 the growth rate was $114.67 \%$. It also draws attention to the increase in the number of persons in collective accommodation facilities (CPD). In 2016, their number was $6,544.8$ thousand people; increased by 116.4 thousand in 2017 , or $1.78 \%$; in 2018 , the number of such persons increased by 345 thousand or $5.18 \%$ (Fig. 2).

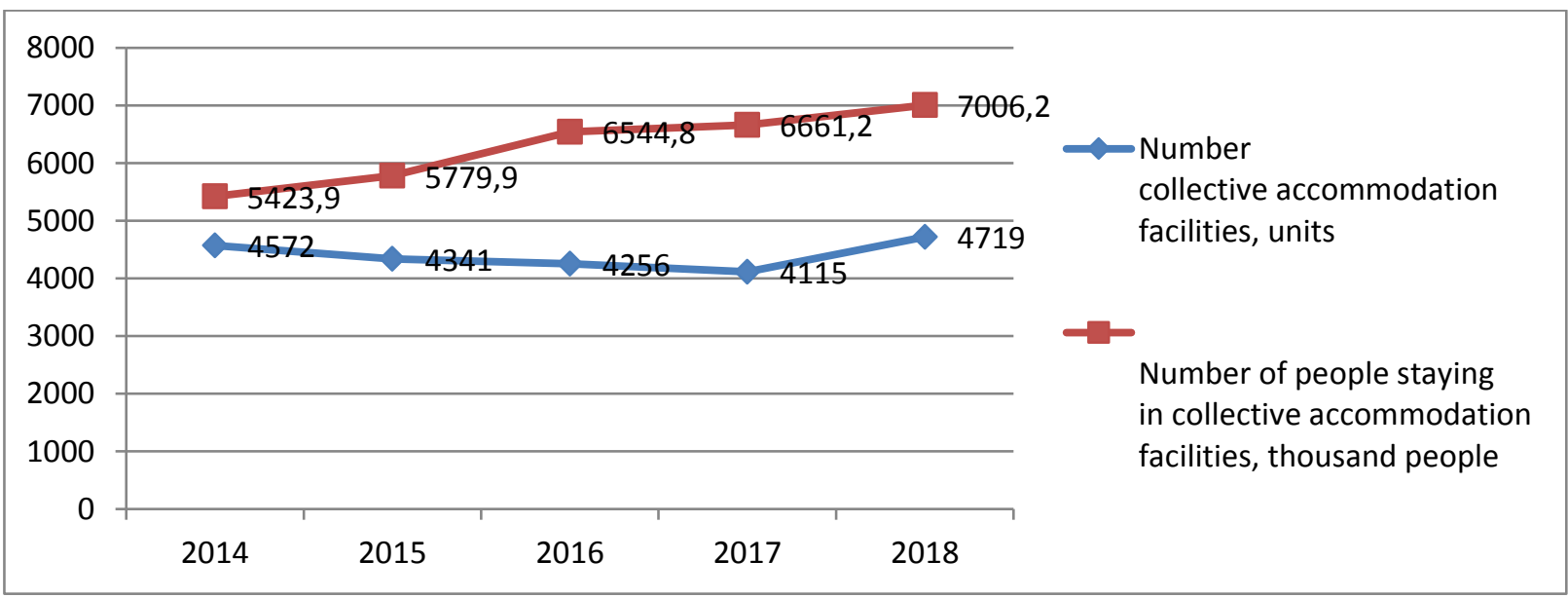

Fig. 2. Dynamics of the number of collective accommodation facilities and the number of persons in them [12] 
A driving factor for the further development of such businesses is that the hospitality industry is faced with a number of tasks, one of which is the desire to attract as many clients as possible, ie to maximize the sale of services, and make it a regular customer. It is impossible to achieve this goal without modern innovative solutions, which requires hotels to develop significantly not only in the technologies used, but also in the perception of a new format of service provision. The multitasking of modern business requires the implementation of egovernance systems that will help to increase the cost-effectiveness of work and improve the quality of services, namely: fast and continuous control over the work, a comprehensive analysis of the hotel and its individual components, accessibility and speed of customer service, etc.

The main channels for obtaining and disseminating information that are currently used in digital marketing, including amongst the temporary accommodation companies, are [13]:

1. The Internet and the devices that give it access.

2. Local area networks.

3. Mobile devices.

4. Digital television.

5. Interactive screens, POS-terminals.

6. Touchscreens, readers, and more.

7. Digital gadgets.

Research on modern information technology used in the hospitality industry has identified several major areas in which these technologies can be classified:

- global distribution systems - reservation and reservation systems;

- complex automated enterprise management systems;

- Use of the Internet and mobile communications.

Booking and reservation systems should provide hotels and their individual elements with quick processing and transfer of information, and provide customers with complete and accurate information regarding hotel location, availability, availability of services, etc. Global Distribution System (GDS) play a paramount role in the automation of these processes. In this regard, the process of GDS implementation in the activity of tourist enterprises of Ukraine is an important task of the state at the present stage of development [14]. Amadeus Hotel and Fidelio are the most commonly used reservation systems in Ukraine. These systems provide complete information on hotel room availability, availability of rooms of different types and their price level in different hotels and guarantee the up-to-date information provided at the time of request and satisfaction of the entire range of customer orders. In addition, using the specified system, it is possible to make a reservation of the selected number at flight rates and to receive an automatic confirmation of the reservation, which reduces the time of customer service and reduces the cost of services. Immediate confirmation and stabilization of request processing helps to increase the interest of clients in using the services of such hotels. But the installation of global distribution systems in small and medium-sized hotels is hampered by the lack of financial resources to install such software, the low level of staff training to work with such systems, the lack of uniform standards for the use of reservation and reservation systems.

Integrated Automated Hotel Management Systems (ACS) are a set of subsystems that ensure the effectiveness of interaction between all counterparties - customers, travel agencies, etc. The ACS is a rather expensive system, but its implementation is necessary if the hotel wants to be successful in the conditions of use of modern technologies and lively competitive struggle. In addition to gaining competitive advantage, it should be noted that the use of ACS will improve the productivity and the most efficient use of all available hotel resources by changing the methodological, technological and informational parts of the hotel management processes, which will lead to an improvement in the quality of services provided. But it should also be 
noted that not all hotels meet the basic requirements necessary to implement such systems. First and foremost, executives need to be aware of the need to improve employee skills today to make greater use of computer technology in the future. This will lead to an increase in the quality of customer service, will allow managers to quickly and more accurately structure the tour, provide a diversified range of tourist services, improve the level of marketing planning development, and increase the competitiveness of services in the market today [15].

The use of internet marketing in the hotel business is important enough to promote hotel services in order to promote them in the market. This gives you more opportunities to advertise hotel services outside your home country without increasing your advertising costs, even reducing them. The use of Internet resources allows you to provide the same amount of information at any geographical point, regardless of the number of visitors to this Internet resource. In addition, information on the Website may be made larger, updated in a timely manner, contain photos and videos, and provide an easy and accessible way to contact and book rooms. However, it should be borne in mind that the creation of a website is not sufficient to produce significant effect, as it will also require further promotion, which will require the organization of targeted campaigns that use aggressive marketing push technology. Not only the Internet but also mobile communication systems can be used to send messages to e-mail and mobile numbers of consumers. The base of addresses and telephone numbers is formed by processing information about past customer references, regardless of the fact that they have used the services or just read them.

The implementation of these measures will improve the reputation, image of the hotel, which in turn will increase the number of customers, make the time spent by customers in the hotel more comfortable and enjoyable, will allow you to work more efficiently, increase their income and level of customer service [16-18]. Moreover, the use of such technologies is currently not so much a factor of competitive advantage as a necessary tool for survival in today's competitive environment.

Conclusions from this research and prospects for further developments in this area. The introduction of modern information technology in the hotel business is a must in the development of the hotel business, as the promptness in processing and providing information that will ensure a high speed of reservation and reservation of seats, the relevance of advertising information, can become a decisive factor in competition. There is a need for continuous improvement of customer service in all its components, which proves the urgent need for the introduction of information technologies. With these technologies, hotels will be able to provide a high level of service, expand the range of services provided, improve the management system, and provide security guarantees for hotels. The use of e-governance systems in hotel complexes will increase the competitiveness of these institutions and increase the level of revenue, and the use of digital marketing tools will expand the customer base. Further development in this direction is promising in Ukraine, as the number of information systems in the hotel market is gradually increasing, and their effectiveness is increased due to the fact that new programs are not adapted analogues of foreign programs, but are developed directly in Ukraine, taking into account local conditions and specifics. Trends in the development of domestic software indicate the possibility of increasing the quality of hotel services to an international level.

1. Oklander M. A., Romanenko O.O. (2015) Spetsyfichni vidminnosti tsyfrovoho marketynhu vid Internetmarketynhu [Specific differences in digital marketing from internet marketing]. Ekonomichnyi visnyk Natsionalnoho tekhnichnoho universytetu Ukrainy "Kyivskyi politekhnichnyi instytut» [Economic Bulletin of the National Technical University of Ukraine "Kyiv Polytechnic Institute"], no. 12, pp. 362-371. 
2. Yatsiuk D. V. (2015) Tsyfrovyi marketynh: maibutnie marketynhovykh komunikatsii v brendynhu [Digital Marketing: The Future of Marketing Communications in Branding]. Investytsii: praktyka ta dosvid [Investments: practice and experience], no. 7. Available at: http://www.investplan.com.ua/pdf/7_2015/16.pdf.

3. Matviïv M.YA. (2014) Formuvannya cifrovogo marketingu pidpriemstv [Formation of digital marketing of enterprises]. Efektyvnist derzhavnoho upravlinnia [Public administration effectiveness]. Available at: http://nbuv.gov.ua/UJRN/efdu_2014_41_32.

4. Ruban V.V. (2017) Cifrovij marketing: rol' ta osoblivosti vikoristannya [Digital marketing: the role and features of use]. Ekonomichnyi visnyk Zaporizkoi derzhavnoi inzhenernoi akademii [Economic Bulletin of Zaporizhzhya State Engineering Academy], no.2, pp. 20-24.

5. Marchuk O.O. (2018) Cifrovij marketing yak innovacijnij instrument upravlinnya [Digital marketing as an innovative management tool]. Ekonomika ta suspilstvo. Mukachivskyi derzhavnyi universytet [Economy and society. Mukachevo State University], no. 17, pp. 296-299.

6. Zubareva M.A. (2015) Golovni trendi gotel'nogo biznesu na digital-rinku [Major trends in hotel business in the digital market]. Ekonomichni litopysy-XXI [Economic Annals-XXI]. Available at: http://soskin.info/userfiles/file/2015/7-8_2_2015/Zubarieva.pdf.

7. Oklander T.O., Osetyan O.M., Hidirov S. (2019) Komunikativni strategiï pidpriєmstv gotel'norestorannoï sferi [Communication strategies of hotel and restaurant enterprises]. Chornomorski ekonomichni doslidzhennia [Black Sea Economic Studies]. Available at: http://bses.in.ua/journals/2019/37_2019/23.pdf.

8. Dan'ko T.P., Skorobogatykh I.I. (2005) Kolichestvennye metody analiza v marketinge [Quantitative methods of analysis in marketing]. SPb.: Piter. (in Russian).

9. Oklander, M.A. (2002). Problemy formuvannia marketynhovoi systemy krainy [Problems of the formation of the country's marketing system]. Kyiv: Naukova dumka [in Ukrainian].

10. Gerasimyak N. V., Dacenko V.V. (2018) Novitni pidhodi do marketingu v cifrovij ekonomici [New approaches to marketing in the digital economy]. Marketynh $v$ tsyfrovomu seredovyshchi [Marketing in the digital environment], no. 17, pp. 83-84.

11. Mal's'ka M.P., Hudo V.V., Cibuh V.I. (2004) Osnovy turisticheskogo biznesa: Uchebnoe posobie [Tourism business basics]. Kiev: Center for Educational Literature. (in Ukrainian).

12. Ekonomichna statistika / Ekonomichna diyal'nist' / Turizm (2019) [Economic statistics / Economic activity / Tourism]. Kiev: State Statistics Committee of Ukraine. Available at: http://www.ukrstat.gov.ua/operativ/menu/menu_u/tur.htm.

13. Digital-art. Digital-advertising [Electronic source]. - Available at: http://www.imagecms.net/blog/polnyirakurs/digital-reklama-kak-eto-proishodit\#imagecms.

14. Gumenyuk N.V., Palamarchuk A.O. (2010) Global'ni komp'yuterni sistemi rezervuvannya: praktika vikoristannya v turistichnij galuzi Ukraïni [Global computer reservation systems: practice in the travel industry of Ukraine]. Visnyk Khmelnytskoho natsionalnoho universytetu. Ekonomichni nauky [Bulletin of Khmelnitsky National University. Economic sciences]. Available at: http://journals.khnu.km.ua/vestnik/pdf/ekon/2010_4_4/061-064.pdf.

15. Zajceva V. M. (2015) Vikoristannya innovacijnih tekhnologij v galuzi turizmu [Use of innovative technologies in the field of tourism]. Zaporizhzhya: Dike Pole. (in Ukrainian).

16. Kononenko T. P., Timofe€va O. M., Usina A. I. (2012) Informacijni tekhnologiï v gotel'nih pidpriemstvah [Information technology in hotel enterprises]. Prohresyvni pryiomy ta tekhnolohii vyrobnytstva produktiv kharchuvannia v restorannomu hospodarstvi ta torhivli [Progressive techniques and technologies of food production in the restaurant industry and trade], no. 1, pp. 563-569.

17. Oklander, M.A., Oklander, T.O., Pedko, I. A., \& Yashkina, O.I. (2017). Marketynhovi doslidzhennia innovatsii ta pidpryiemnytski ryzyky [Marketing Research Innovations and Business Risks]. Oklander, M.A. (Ed). Odesa: Astroprint [in Ukrainian].

18. Oklander, T.O. (2011). Innovatsiini metody vplyvu na spozhyvachiv: aromamarketynh [Innovative methods of influencing consumers: aroma marketing]. Marketynh i menedzhment innovatsii-Marketing and management of innovations, 3, 97-101 [in Ukrainian]. 
Серьогіна Н.В., канд. екон. наук, доцент, доцент кафедри економіки та підприємництва, Одеська державна академія будівництва та архітектури (Одеса, Украйна).

Петрищенко Н.А., канд. екон. наук, доцент, дочент кафедри економіки та підприємництва, Одеська державна академія будівництва та архітектури (Одеса, Україна).

Андрліч Б., д-р екон. наук, професор, Політехнічний інститут Пожеги (Пожега, Хорватія).

Цирровий маркетинг в готелях.

У статті проведено аналіз наукових джерел, який виявив, щео ичфровий маркетинг зараз $\epsilon$ найбільш актуальним для підприємств будь-якої галузі і використовується різних типах ринків. Виявлено, що його перевагою є різноманітні інструменти і інтерактивна форма, що дозволяе кінцевому користувачеві отримувати актуальну інформацію про ресурс, залитати коментарі та розширювати коло зацікавлених сторін, що позитивно впливає на коло стейкхолдерів. Наведені основні інструменти ичиррового маркетингу, розроблена схема градації використання иифрового маркетингу за типом і широтою можливостей. Встановлено, щзо неможливо ефективно використовувати цифрові маркетингові заходи і інструменти в діяльності підприємств готельного бізнесу без подальшого обслуговування, особливо в сфері готельного бізнесу.

Ключові слова: цифровий маркетинг; інтернет-маркетинг; інструменти цифрового маркетингу; готельний бізнес; цифрові технології.

Received to the editor June 8, 2019. 